\title{
What Is Left Unsaid on Commentaries on 'Al- muaalqat': Ibn Al-anbari as a Model?
}

\author{
Ahmed Al-Harahshah \\ Al-Albayt University, Jordan \\ Khaled Al-Badayneh \\ Arabic Department, Tafila Technical University, Jordan
}

\begin{abstract}
This study aims at excavating the unsaid in Mohammad Bin Al Qasim Al Abari's analysis of Imru" Al Qais and Tarafa Ibn Al Abd Mualaqas. The study attempts to reevaluate Al Anbari's (1965) misinterpretations resulting from neglecting the context and the motive behind the composition, as well as the failure to appreciate the connotations and sticking only to dentations, which resulted in losing the gist of the texts.
\end{abstract}

Index Terms - The Unsaid, Reception, Context, Hyperbole

\section{INTRODUCTION}

There are various literary works that attempted to explicate 'Al-Muaalqat', the ten most well-known masterpieces of Arabic poetry before Islam, but they did not intersect with both earlier and latter works, for instance Al-Anbari (1965) who passed away in 940 AD in his work 'Sharah Al-Qassaiyed Al-Sabaa AL-Tawaal Al-Jahaliyaat' and Sheikh Ahmed Alameen who passed away in 1974 in Sharah Al-Mualakaat Al-Ashar, have not added much in terms of explication and commentary on the suggested meanings (1).

It is known that the Ancient Commentators on Arabic literature was interested in providing commentaries on particular aspects of grammar and rhetoric, issuing some spontaneous impressionist judgments, discussing some issues of pronunciation, meaning, form, content and stealing poems, all at the expense of the meaning, which remained unchanged in all subsequent commentaries written by Al-Anbari (1965); this lead to the fixation of the dictionary meaning in the Arab memory regarding both place and women names throughout the different periods of Arabic poetry.

If we examine the Ancient Commentaries very carefully, we can find explicit violations of scientific and human truths, and a clear ignorance of social and psychological data, historical facts, and a clear break of the horizons of the recipient's expectations, so that the commentator will look at the texts grammatically, morphologically, and rhetorically at the expense of the meaning intended by the poet at a particular emotional moment generated by an event dominating the poet's artistic imagination; regrettably, the commentator intervenes to restrict these meanings to the ones defined by dictionaries away from the reasons for creating the poem, its occasion and context, and the real intentions of the poet, ignoring the depth of the text and its significance, the poet's emotion and mental preoccupation with trivial issues not related to the context of the poem. The commentaries have become lessons of limited usefulness in the language sciences, because what important is to increase the recipients' understanding of the meaning of the text, but not to hold them back from the intent of the text and the poet together and force them to believe forcibly.

The ancient analysis of Arabic poetry before Islam indicates that the old Arabic poem is hardly connected with a range of themes, so that modern critics constructed their vision on it, going further by arguing that Arabic poetry is characterized by the presence of diverse, unrelated topics only connected by rhythm and rhyme. It is true to say that every high text of the timeless texts encapsulates one emotion stimulated by motivations within the psychology of the poet, which lead to the birth of the text.

The analytical potential offered by the Arabic language sciences in terms of syntax, morphology, and rhetoric does not help the critic to elucidate the poetic potential of language, which is the main concern of both ancient and modern critical approaches. This led to blocking channels of communication and interaction with this poetry, which has worsened over the ages until it has become odd for the current generations. This means that poetry does not use language merely for conduction, nor does poets use it to indicate specific meanings, as there is a constant change from time to time, from culture to culture and from one social class to another (2).

\section{A. Goals of Study}

Injustice that falls on Arabic poetry and the poet himself before Islam and dragging the ancient criticism towards fake commentaries led to distorting its image, uncovered the features of its unity, and made it a heresy as opposed to world literature, lacks any form of thematic unit. Based on these considerations, the poem seems to be dispersed on several unrelated topics except for the rhythm and rhyme because the Ancient Commentators neglected the occasion and 
context of the poem itself, stripping away the words from the circumstances in which they are used and merely highlighting the word meaning, which opened the door widely for criticizing the Arab mentality critically, and including that of the Pre-Islamic Era.

\section{B. Hypotheses}

It can be assumed that Ancient Criticism opposes the reality of the Arabian life, the psychological state of the poet while composing his own poem, the conditions of the stages of lifetime, and states of human emotions; this resulted in distorting the image of poetry in the Pre-Islamic Era and the image of the Arab mind together in contrast with the truths that suggest the soundness of the Arab mind producing this ultimate fine literature that tops world literature.

And that the Arab poet in the Pre-Islamic Era has a great imaginative ability to show what he wants and conceals what he wants without a concentration on superficiality, which also proves that the poet in that era was arranging his ideas when producing his poem, so the poem's images are interconnected in the sense that the images altogether stick to the main theme of the poem.

\section{LITERARY ANALYSIS}

The Ancient Commentaries in particular and Arabic poetry in the Pre-Islamic Era in general was so naïve and superficial that the critic engaged in clarifying the dictionary meanings of the lexical words and also engaged in focusing on the syntax, morphology and lexis of the words used, never trying to explore the layers of meanings to look for 'the meanings of seconds' as called by Hazem Al-Qartagni; the contextual meanings are simply related to the real functions and intensions of speech and style of poetry is wholly dependent on it. The words and phrases in poetry have unexpected dimensions, because the poem is nothing but a special composition of a group of words of the language (3) ; therefore, in the interpretation of poetic texts, the direct linguistic meaning is not the main target, especially when it contrasts sharply with the context of the situation (4).

It is not possible to understand the purposes of literary texts of high value from the first reading, which no longer enriches the initial meaning given by the first reading, because the first reading cannot cultivate the purposes, as the poet does not refer to the sentence meaning, but to other meanings (5). The Ancient Commentators were primarily concerned with the lexicon and did not take into account the context of the situation, so that they were merely interested in lexical meanings (6).

\section{A. What Is Left Unsaid in Muealaqat Amri Alqis}

How did Ibn Al-Anbari (1965) receive these poetic lines?

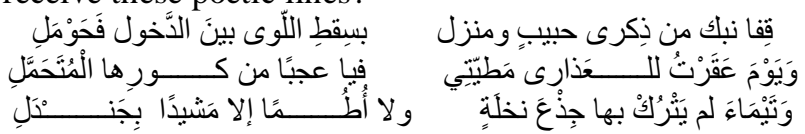

In the first poetic verse, Ibin Al-Anbari (1965) introduced Muealaqat Amri Alqis with the story of the spring of Darat Jiljal, suggesting that the poem of Amri Alqis was the result of that event where he concluded it with some poetic verses of his own (7):

$$
\text { حتى إذا كان قرييًا من الحي نزل فأقام، حتى إذا أجنَّه الليل، أنى أهله }
$$

After he confirmed the first poetic line, he started to analyze the word "Qifaa", commenting on the use of the dual form and citing Qur'anic verses and poems. Ibin Al-Anbari (1965) also stated the opinion of Kasa'i in relation to "Qifaa", "that "Qifaa" is originally preceded by 'L' and altogether understood as 'Litqifaa' and continued to justify the dropping off of 'L' until he came across the following poetic line said by Amri Alqis:at this point, he was mainly concerned with the linguistic interpretation partially based on the opinions of some Arabic scholars and evidenced by some Quranic verses and poems (8).

Then he comments on the proper noun "سقط اللوى " , the first word of which takes three forms (i.e. 'Sigtt', 'Sugtt', 'Sagtt'), tells us about what the linguists said about, and finally talks about the presence of 'b' in initial position in the above linguistic forms.

What we can conclude from these examples that the above cannot be described as a good commentary on deep poetry, which is not merely separate words devoid of the context of the text. In other words, poetry should be understood beyond the lexical items and it uncovers the ability of the poet to go beyond the meanings of normal circumstances. This is simply because the Ancient Commentator did not associate speech with the context of the text itself, so that they were merely concerned with the meanings of the lexical items, ignoring the importance of the poem's occasion and rationale. This commentary led to breaking the poetic line itself into pieces and the poem as a whole so we are no longer able to distinguish the literary from non-literary discourse. If Ibin Alanbari(1965) had been alive, we would have asked him the following questions:

1. Why did the crying and separation not take place, and they all returned to the neighborhood?

Shouldn't he laugh and say:

$$
\text { وهن عاريات على غدير دارة جلجل قفا نضحك من ذكرى نساء أهلي }
$$


It seems irrational that Arabs in the Pre-Islamic Era enjoy the seeing of naked women (particularly those who are considered as relatives), so they typically tend to display real Arab values through protecting the chastity and honor of their young female relatives, as normally do Arabs:

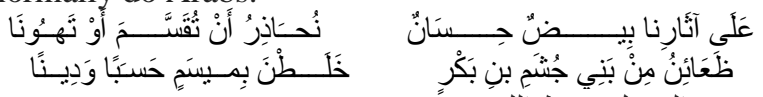

2. What is the interrelationship between place names such as الدخول, سقط اللوى جلجل, on the other hand? These places are distant from one another and they are not related at all.

3. Did Abin Al-Anbari (1965) not ask himself that how a man asked both of his friends to cry with him for his beloved? Is it typical of human beings to do that? How about the jealousy of the lover? Is this behavior not acceptable to all faiths, cultures, and nations? By the way, we did not see any of the Ancient Commentators and others rejecting this behavior, except for Abu Bakr Al-Baklani in his book 'The Miracles of the Koran' (9).

If it is required for the lover to stand in a wailing manner, the speech in this respect is acceptable, but the meaning is spoiled from another angle, because it is absurd for the lover not to be jealous for his beloved, and to invite others to say what lovers say to their beloveds (10). But Imru Al-Qais does not cry over his beloved and the story of Daratu Juljuli is not correct, as there are no such places in Najd and Daratu Juljuli is actually in Yemen; Al-Hijri said about that: Daratu Juljuli is located in Yemen where there was a battle between Kinda and Bjela , on the one hand, and the tribe of Khatham, on the other hand, the latter of which were victorious at the end (11). This victory was proudly celebrated by Al-Khathram Balajali in one of his poems:
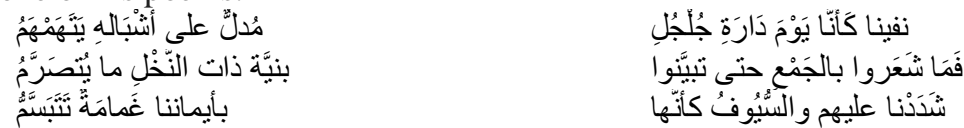

The events of this story cannot occur in the Arabian Peninsula in the Pre-Islamic where Arabs are the most jealous people for women (12).

\section{B. What Is Left Unsaid in the Second Poetic Line

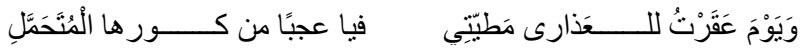

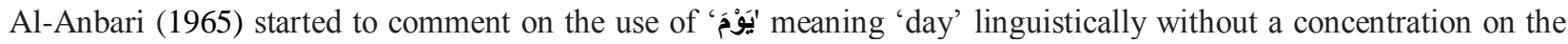
real literary meanings. To assert his right commentary, he resorts to providing Quranic verses and poetic lines from other poets. For instance, he is overwhelmingly engaged in contrasting opinions of syntacticians on the grammatical functions of lexical items in the second poetic line, providing different linguistic forms of the word 'العذَارَى'. He also said: "What a wonder for her enduring journey" means I did this due to foolishness in my youth. In addition, it was narrated that he created the poem the same day at night! What is the interpretation of this?

Finally, it seemed odd that Al-Anbari (1965) did not have a rethink while trying to comment on the second part of the poetic verse. How the relevant women in the verse endured that nomads were carried in their Houdj, a relatively small tent placed on the back of a camel to carry a woman/women. Let us ask ourselves this question: Did Al-Anbari (1965) not ask himself why Imru Al-Qais prepares his own travelling camel for the women of his people (13), even though there are many camels with their young ones in the camel train (14). Camels and horses have a special place in the hearts of Arabs as they are easy to be controlled, are smart, and remain close to their home (15).

The word "العذارى" meaning 'virgins' relates to every woman that does not have any sexual relation with men (16). Allah allows a woman to marry a man except for Mary Bint Omran, Peace be Upon Her, the mother of Messiah, Peace be upon him, in order to order to achieve the miracle of the birth of Jesus (peace be upon him). Arabs are not fond of virginity, neither in their social nor in religious values. It exists among nuns working in monasteries, who tend to be virgin following Mary Bint Omran. The Arabs did not associate 'virgins' to the girls, but called them 'firstborns', 'meaning 'girls whose breasts have just grown and taken a shape', and 'الأوانس' meaning 'girls who are so sociable that they remove any worries and concerns from the people around her', and likened them to antelopes and others. When عذارى is mentioned in poetry, it normally relates to nuns working in monasteries, as mentioned by Imru Al-Qais in the following verse:

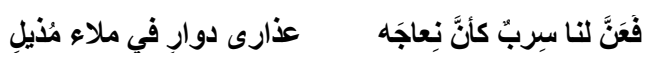

Imru Al-Qais alighted his camel on another day because the day of Darat Juljil is preceded by a conjunction so he said:

The good days in the life of Imru Al-Qais are more than a day, if he was talking about one day, he would not favor the use of the conjunction" و'; the first day was the day of victory in the location of Darat Juljil, and the second day was the day when he stopped his camel for the virgins of one of the monasteries for the sake of God. It is known that virginity in the Arab culture before Islam was a kind of sanctification and respect based on the virginity of the workers in the monasteries, and the monasteries were scattered in the northern and western parts of the Arabian Peninsula (17).

So he was afraid of composing love poems describing them for something bad that may happen to him, even though he did not hate their qualities or they did not hate his qualities, so he said in another poem:

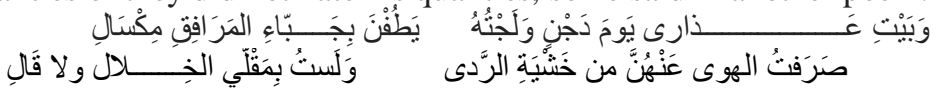

Imru Al-Qais warns against making romantic advances to the virgins in fear of revenge by the Lord for anyone tries to damage their images (18), as happened with one of the kings of Iraq when he wanted to bring some virgins 
"monastery virgins" by force in the outskirts of Mosul near Raqqa; According to the narrative by Al-Hamwi (1979): " one of the kings of Iraq was told that there are very beautiful women, so ordered him to bring them to choose by himself (19), so when the virgins heard the news, they prayed fasted that day for God to save them. Because of that the king died at the same day" (20).

What is left unsaid in the third line?

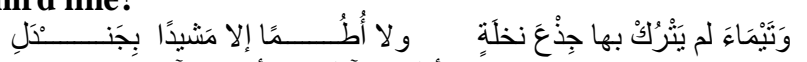

After Al-Anbari (1965) mentioned 'الأطم والآطام والأجم والآجام', which are the roofed houses, he explains the second half of the poetic line, supporting his argument by stating some poetic lines said by Oday Bin Zaid and Qays Bin AlKhateem. Did Al-Anbari (1965) himself not ask himself what the function of this exception is and why did Amru AlQais exclude this الأطم from the other ones?

This rain is an exaggerated rain and it only occurred in the flood of Noah; this type of exaggeration may happen when the poet attempts to do as much as possible to describe the thing. In this respect, Al-Hatami believes that it is the creativity of the poet who takes care of virtue, so he resorts to the act of not telling the truth. Actually, this hyperbole is mainly intended to exaggerate (21), and the exception, carried out by the poet Amru Al-Qais, of one of the small hilltops to be destroyed by rain is really a nullification of exaggeration and hyperbole. The poet was known by using exaggeration and hyperbole in his poetry, as in the following line:

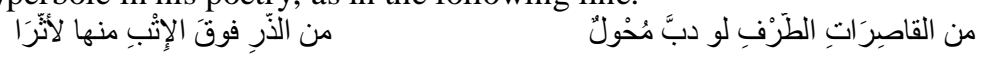

We may wonder about why Amru Al-Qais ceases the use of hyperbole and exaggeration when he reduced the ability of the rain to demolish all the small hilltops that stand in his way, with the exception of the sands constructed in Jandul (22). He then examined the power of the rain until he declared that there was no power that can stop rain.

If exaggeration in poetry is reduced, it is all spoiled, and if exaggeration invalidated, all analogy and metaphor become a defect. The bottom line is that the more excessive hyperbole and exaggeration in poetry, the higher quality it has. It is conceived as a good example of exaggeration in poetry that arouses the appetite of the recipient to listen and follow, simultaneously charging minds with fits of imagination to the extent that emotions are greatly stimulated, as exemplified in the emotions of intimidation, admiration, sadness, and pity in order that poetry fulfils its message and objective.

As for the imagery of rain, this can be conceived as an instance of exaggeration, but it is just a wish to avenge himself on the tribe of Bani Saad, hoping that torrential rains fall over the houses of Bani Saad and destroying them all. That is why the image of the rain was the last one in this poetic masterpiece.

Based on the clues that we have in this literary masterpiece, we can assume that the poem was composed during the youth time, and that it is one of the fruits of the incident of Daratu Juljuli that violated the values of Arabs in the preIslamic era, and supports what we see that Amru Al-Qais said his poem after leaving the fortress of Samoel to the Levant. He said it there on the bank of the Euphrates between Hamer and Ikam from Raqqa (23):

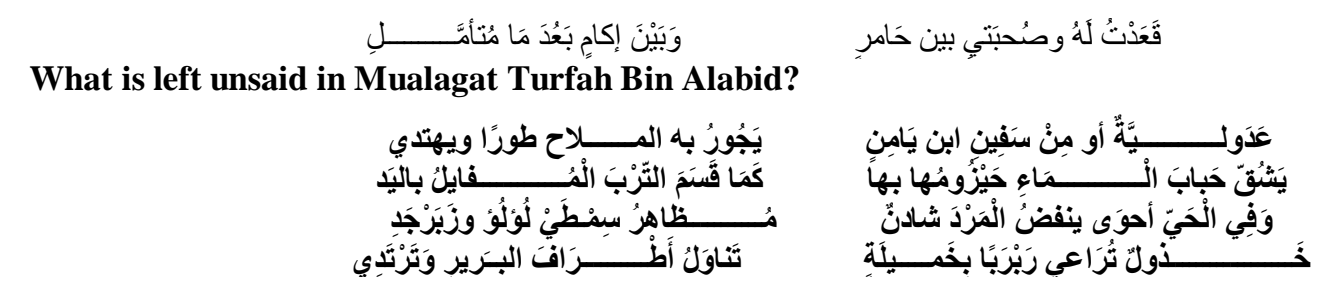

Al-Anbari (1965) conveys the opinion of Ahmad Ibn Obeid in Adawliya and says it refers to an island called 'Adawli' down Oraal down Amman and he continues elaborating on this word linguistically. Doesn't Anbari (1965) ask himself what he meant by "blinking and guiding". Is this usually a special way of commanding international ships? What does he want to add to Adawliya? Is there any new meaning? Couldn't he be satisfied with referring huge ships to Adawliy, a metaphor for hugeness and greatness. In this respect, the figures of speech used achieved its purpose, but he praised the greatness of the ship, and then reduced the practices of the navigator. Does he insinuate that the defect in the ships is related to its navigators? We think that this is not the right explanation because the navigators of large ships are often equipped with long experience.

When we go further back, Adawliya is similar to Hadouj Almalikieh, related to the sons of Malik Bin-Dhubia BinQais ibn Thalba Al-Bakri, According to the historical events, Turfah Bin Alabid was expelled from his tribe and went homeless for a while. It is well-known that the leader of the tribe is actually responsible for expelling him from the tribe, so he keeps criticizing the leader of the tribe as a person not knowing how to lead the tribe properly. This means the second half is not meaningless but he criticizes the tribe's Sheikh as an idiot man leading the tribe members to destruction, poverty, and homelessness (24).

Therefore, Turfah Bin Alabid blames the tribe for the animosity between them and the tribe has started it. The poet has held the tribe's Sheikh responsible for what happened to the tribe (i.e. division as a result of injustice that falls upon its members), so he says the following poetic line:

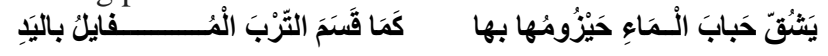


To confirm what we pointed out, in another poem, Turfah Bin Alabid praises his tribe Bani Bakr and criticizes the tribe's sheik as not being qualified enough for leadership, and that such a great tribe needs a sheikh worthy of it (25):

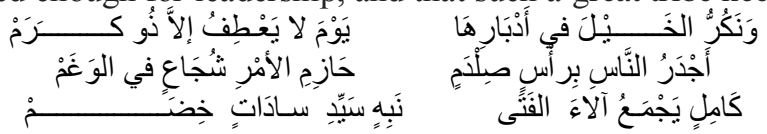

In another poem, Turfah Bin Alabid spreads out his complaint, pain, poverty and alienation of his tribe Bani Bakr (26). He is eager to return to them, and live among the confines of their homes, so he says the following:

What is Left Untold II

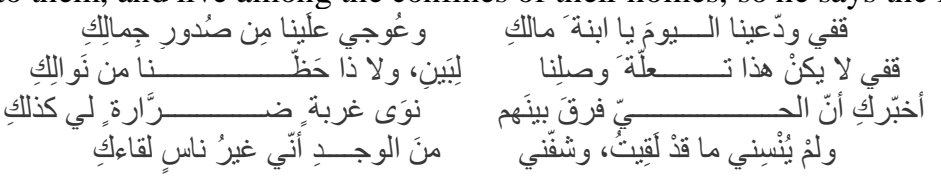

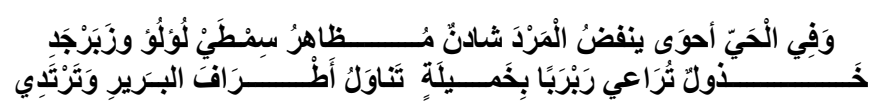

Al Anbari (1965) started by introducing Al-Ahwa (a black-faced or brown-lipped deer). He referred to a deer with two black lines, but he means the blackness of its tears, so he compares the woman to a deer, the most intimate metaphor for her. When he says, "ينفض المرد", he means that the deer lifts itself up to eat the fruit of Arak (Salvadora persica), but "النفض" fells down on it; "النفض" is all that fell from the tree. Then, Al Anbari (1965) cited a verse of Abu Dhuib al-Hadhli on the fruit of Arak, saying: Turfa says :the deer shakes off the fruit of the tree (Arak) with its horns; "الثشادن" is the little deer that has started to move and almost dispensed with its mother.

Ahmad Bin Obeid says: "ينفض المراد" means playing because it has been full, then he cites words of Ibin Muqbel on playing after satiety. Ghair Ahmad Bin Obeid said “" مظاهر سمطي لؤلؤ", meaning wearing a necklace of pearls over another; and, finally, Al Anbari (1965) identified its syntactic position.

Then when he moved to the second line, he said that "خذول" is the one that failed its companions and set up on taking

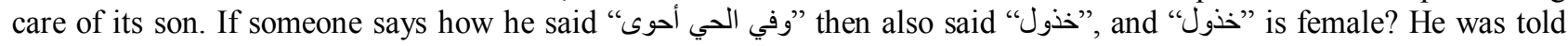
that this was a sort of analogy: she is a deer-like woman in the length of her neck and beauty, and a cow-like in her good eyes. When he says, "تر اعي ربربا", he means that the deer grazed in the lush thicket with herds, because it failed its companions and herds, only grazing with cows. It would be more letting down if it has little deer. He singled out "الخذول" in two ways. First, it is panic at and passionate about its kinds; it stretches out, extends its neck, rises, and grazes. Second, it holds aloof, which is better for it, because if it had flocked in her herd, it would have been hard to display its goodness. "الربرب" is the flock of deer and cows as explicated when citing poetic lines on " to prove that "تنول" is the flock of cows and deer, not cows alone. His saying the deer nibbling tips of the Arakfruit, and his saying "ترندي" suggests that the tips and branches of the Arak tree are wrapped in the deer's cloak. Finally, after he had come up with verses about "تري"، "ترتي", he said that "الخذول" is an adjective for Al Ahwa, revealing its syntactic position (27).

Al Anbari's (1965) contradiction is apparent and his disorder is outrageous in his desperate attempt to combine opposites with meanings, so he is easily found unable to remember what he said in his previous sentence; meanings are worn together; adjectives are arbitrary attached; and texts are twisted to respond to his opinion.

Al Anbari's (1965) contradiction in explaining these two poetic lines are many and exhausting to him and to readers together, including:

- Al Anbari (1965) said that Turfa likened the woman to a deer, but where were metaphor conditions? Where was the metaphor? The first line is devoid of it. And what is the similarity between a woman and a fierce little deer weaned and almost dispensed with its mother, hitting Arak trees with a horn?

- He said "ينفض المرد": it stretches its neck, "النفصو" is stretching its neck softly and quietly.

- He said that it shakes off the fruit of Arak with its horns; and shaking off "النفض" indicates infertility and that the tree has little fruit left.

- Adopting Ahmad Bin Obeid's take on the meaning of "لالنفض" to be "playing' because it has been full and is no longer hungry, is a mistake because playing after satiety is living in opulent comfort, away from the need for food.

- When he tried to bring the similarity, he said that the woman is like a deer in the length of her neck and beauty, and like a cow in her good eyes. From where did he fabricate this similarity even though it was not clear in the text? He took that the deer eyes were prettier than those of the cow, and the deer beauty would have been distorted if the eyes of the cow had been put into the deer.

- He said "تر اعي ربربا" which means that the deer failed its companions and herds, only grazing with cows. His

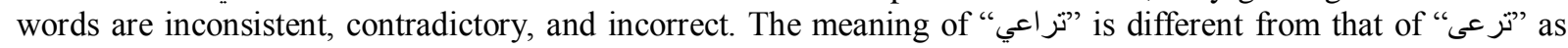
"تنرعى" means taking care whereas in the sense of eating. So how did it fail its companions while eating with a cow herd? Why the deer was called "خذى" "خذول" because it had left its herd and grazed with cows? Al Anbari (1965) has fallen into a big, obvious dilemma, but he attempted to remedy the situation, saying that the deer lets down when it has little kids. 


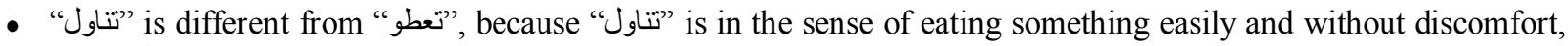
and "تعطو" means the need for stretching its neck since the thing it is looking for is not easily accessible.

- Al Anbari (1965) said: "خذول" is an adjective for the deer, but what are the characteristics they share? "الخشف" is a little deer weaned and almost dispensed with its mother, and "الخذول" is the mother caring for and nurturing its son. "الخذول" is a subject to an omitted predicate, and the implied meaning would be "وفي الحي خذول".

\section{My personal take on these two poetic lines:}

Turfa says there is a little brown deer in the neighborhood which has grown a bit older, almost dispensed with its mother, trying to get its share of the fruit of Arak using its horns, and wearing two necklaces of pearls and aquamarine one above the other, so which is this little deer? Ibin Rashiq says the little deer was used metaphorically for a beloved. If we accepted his opinion, what would the beloved's description be? Little? Brown? Fierce? Are these descriptions popular with Arabs? The answer is no. The beloved Arab woman is shy, not too spoiled, and impregnated with whiteness. Imru Al-Qays said:

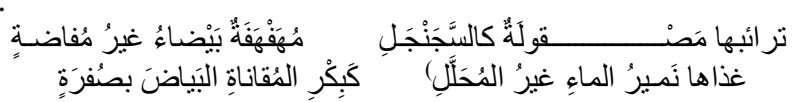

And Al-A'sha said:

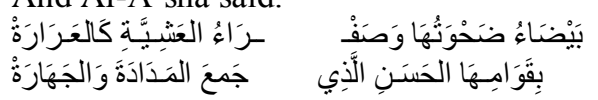

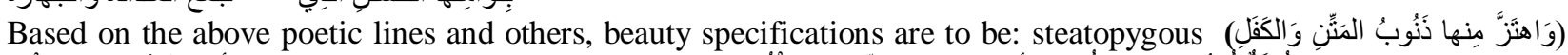

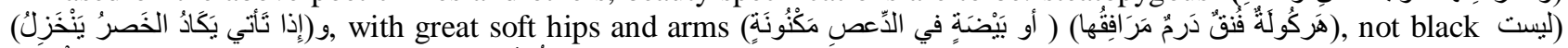

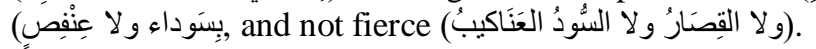

And what the two necklaces of pearls and aquamarine the girl is wearing? It's in the opinion of Ibn Rashiq, Al Anbari (1965) and all other interpreters that she is Turfa's beloved ( For further information see Endnotes 28-36). They said it is a brown deer with two lines of darkening tears, so how did black tears appear on the brown face?

Therefore, what did the poet mean by a little brown deer with two lines of black tears? What benefit did it add to the descriptions of the ferocious little brown girl from further describing the brown deer as having two lines of black tears? Perhaps one would say that the poet meant by brownness that of the lips not the face (37). As a response, I would say: if he intended the brownness of the lips, he would have come up with a presumption as Thu Al-Ruma did, saying:

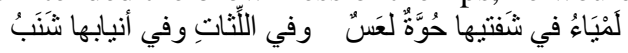

Only the face is described by being black (38).

Al-Ahwa was also mentioned in Ta'bta Sharaan's nephew when lamenting a tramp of Arab brats (39):

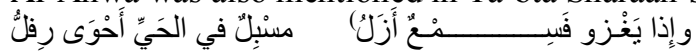

Did the poet flirt here with this tramp? Did he mean the brownness of the lips? Where is flirtation in all this? We don't see any sign of longing and vigilant love common to any lover.

Is it the time to discover this little black deer that grew up and steered to live independently from its mother? It is Turfa himself because he is, according to Al-Marzabani, "a blue person with a black tongue like that of a deer." The two necklaces, "مظاهر سمطي لؤلؤ وزبرجد", is the blackness of the face and tongue; Arabs are proud of the blackness/brownness of men's faces, but they detest the whitish red color of Non-Arabs (40).

As for the rest of the verses of the poem, he spoke of his mother "Warda", who had failed her people when they had deprived them from the legacy of his father, so she worked hard to raise her son without the help of his uncles until he grew up and started asking for his rights with his sword. He moved from the little Ahwa in the first line to Ahwa's mother, Warda who nurtured her son and took care of him in a simple outlying house, living on the margins of life,

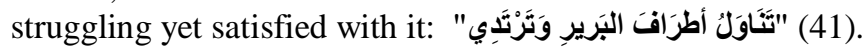

Al-Anbari (1965) and other interpreters have been very much involved in explaining this poetic line, saying that the

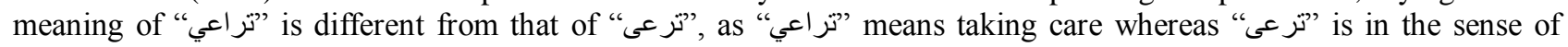
eating. Zuhair Ibn Abi Sulma said in the same sense (42):

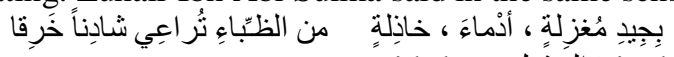

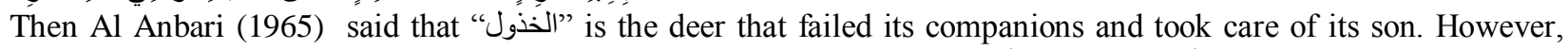
when explaining the line, he got deluded by the lexical significance of "الربرب"; also mean small children (kids) whose mothers take great care of them. Ibn Manzoor mentioned this sense in the words of Allayhani (43):

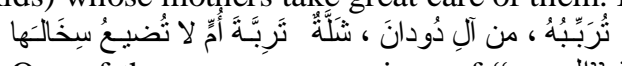

One of the common meanings of "الربرب" in "iste-Islamic poetry is "a herd of wild cows and deer"; the word is not confined to one indirect indication, and each word is a world of senses, some of which are still common in use, but others have been either frozen or left. It seems to me that the deer is the most compassionate and caring mother (44). Amr Bin Qumaia said (45):

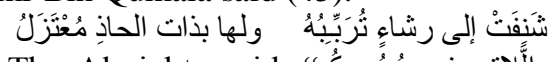

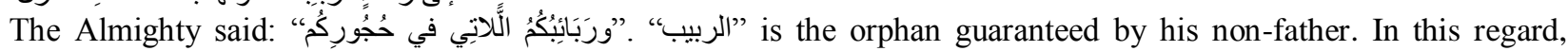
Antara said (46):

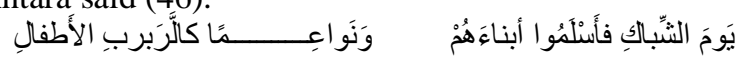

\section{CONCLUSIONS}


Poetry was never a lexical glossary of words, but it is a melting of the poet's spirit. The images are already complete in the mind of the poet and describe emotions and sensations that the poet holds. Words are a mere tool to describe the poet's emotional states that are about to kill the poet if there was no way to speak them out .

Poets do not think of words, but think of images, mental images turning on the tongue, whose turn is to transform these images into verbally interconnected images to give the intended meaning, finding difficulty to transform the poet's images in many other contexts. The word has no value out of its context, so the dictionary lexical meaning does not help to determine the dimension of the word in usage. In other words, the real meaning depends on the context of the situation, as displayed throughout the two masterpieces of Arabic poetry in the Pre-Islamic Era .

What the Ancient Poetry Commentators have done so far cannot be viewed as a real literary explication worthy of consideration, but it is merely a lexical research and closely connected to linguistic sciences that use poetry as a source of linguistic evidence, so that the Ancient Commentators have not focused on the real images in the mind of the poet, opening the door widely for casting doubts on Arabic poetry. For example, it negatively contributes to strengthening the image of Arabs as Nomads merely interested in writing love poems on women and satisfying their sex desires, which control elderly people more than the young generations.

We have to reread Arabic poetry in the Pre-Islamic Era carefully and consciously to reach the real meanings of the texts encapsulating the poet's spirit, but not the meanings provided by dictionaries. Not only the efforts of Ancient Commentators, who exclusively focused on marginal issues without a concentration on the real meanings of Arabic poetry, should be considered to explain and interpret this poetry, but Contemporary Commentators should revisit all masterpieces of Arabic poetry and explicate them according to the latest critical approaches in order to probe into the depths of the poet and access to his own unique world.

Endnotes:

(1) The most well-known Commentaries on these masterpieces of Arabic poetry include The Commentary on the Seven Masterpieces of Poetry by Abi Bakar Alanbari who died in 940 AD, The Commentary of Well-known Poetry Poems by Abi Jafar Al-Nahas who died 950, and others.

(2) Abu Zaid, Nasar Hamid: Ishakaliaat Algaraah waalayaat Altaweel, Arab Cultural Centre, Casablanca, $1994:$ p. 47.

(3) Al-Garttajani, Hazim: Minhaaj Al-Bulagaa wasiraaj Aludabaa examined by Muhamad Al-Habeeb Bin Khawajah: $\mathrm{p} 24$.

(4) Ismael Izaldeen: Contemporary Arabic Poetry: Issues and Its Manifestations. Dar Alawdeh wadar Althagafah: 1981, p. 50.

(5) Asfour, Jaber: Artistic Imagery in the Arab heritage of Criticism and Eloquence. Cultural Centre, 1992, pages 356-357.

(6) See Algirawanii, Abu Ali Bin Rahiq: Al-Omdeh fii Mahasan Al-Shaar Wadabeh examined by Muhii Aldeen abed Alhameed: Beirut Dar Aljeel 1981: page 93., and many others.

(7) Al-Anbari, Abu Baker Muhamad Bin AlQasim: Sharah AlQassad Alsabaa Altawal Aljahiliyaay, ABidalsalam Haroun (passed away) House of Knowledge : page 15.

(8) Sharah AlQassad Alsabaa Altawal Aljahiliyaay: Page 18.

(9) Albaqalanni, Abu Baker Muhammad Bun Al-Ttayieb: Aijaz Al-Quran, Beirut, Dar Alkutab Almiyeh, 2008:m page 107.

(10) Aijaz Al-Quran: page 107.

(11) Al-Jindeel, Saad Bin Abdullah, Muajam Al-Maken Alwardeh fi Almulalgaat Al-Ashar, Riyadh, Idarat AlThagafah Walanshar Aljamiyeh, 1990: page 189.

(12) Al-Bakri, Abdullah Bin Abed Al-Aziz Al-Andalusi (478 H): Mujam Maustuajim examined by Mustafa Al-Saqa, Beirut, World of books, 1983: page 59.

(13) Sharah AlQassad Alsabaa Altawal Aljahiliyaay: Page 34.

(14) Sharah AlQassad Alsabaa Altawal Aljahiliyaay: Page 34.

(15) See Hadith No. 6498 in Al-Bukhari and 2547 in Sahih Muslim, narrated by Abdullah Bin Omar.

(16) Ibin Mandhour $(690$ H) The Tongue of the Arabs, Beirut, Dar Saadir, 2000.

(17) Ali Jawad, Almufadhal fi Tariikh Alarab Qabal Al-Islam Beirut, Dar Al-Alim Limalaaiin, Bagdad, AL-Nahdah Bookshop, 1980: 589.

(18) Alkandi, Imru Al-Qais: Diwan Imru Alqais eexamined by Abed-Alruhman Almastalawi, Beirut, Dar Almaarifah, 2008: 138.

(19) Al-Hamawi, Yagout (626H): Mujam Al-Buldaan, Beirut, House of Arab Heritage Revitalization and Foundation of Arab History: page 352.

(20) Mujam Al-Buldaan, page 352.

(21) Al-Umdeh Fii Mahasin Alshaer waadabeh, page 61.

(22) Diwan Imru Alqais, page 97.

(23) Al-Jader, Mahmoud Abdullah: A contemporary reading of Texts from the Poetic Heritage, Bagdad, House of Public Cultural Affairs, 2002, page 85.

(24) Sharah AlQassad Alsabaa Altawal Aljahiliyaay, page 135.

(25) Al-Jundi, Ali: Tarafah Bin Al-Abed, House of Arab Thought, pages 133-138. 
(26) Sharah AlQassad Alsabaa Altawal Aljahiliyaay, page 135.

(27) Sharah AlQassad Alsabaa Altawal Aljahiliyaay, page 142.

(28) Al-Umdeh Fii Mahasin Alshaer waadabeh wanagdeh, page 225.

(29) Al-Shamantri, Alalam: Ashaar Ashaara Al-Satah Al-Jahaleen examined by Committee of Arab Heritage Revitalization, Beirut, House of New Horizons, page 34.

(30) Alashaa , Mimoun Bin-Gais, explicated by Yousef Shukri, Beirut, Dar Al-Jeel,1992, page 116.

(31)Diwan Alashaa, page 145.

(32) Diwan Alashaa, page 145.

(33) Diwan Alashaa, page 145

(34) Diwan Alashaa, page 92

(35) Diwan Alashaa, page 92.

(36) Jundal, Salameh Bin Jundal: Diwan Salameh Bin Jundal, Sanat Muhammad Bin Alhassan AlaHawal, examined by Fakhar Al-Adeen Qabawah, Beirut, House of Scientific Books, 1987, page 223.

(37) Sharah AlQassad Alsabaa Altawal Aljahiliyaay, page 139.

(38)Thu Al-Rumah, Ghilaan Bin Uqbah, Diwan Thi Al-Rumah, Beirut, Dar Alarqam, 1998, page 65.

(39) Ibin Mandhour $(690 \mathrm{H})$ The Tongue of the Arabs, Beirut, Dar Saadir, 2000.

(40) Shaer Taabatt Sharan examined by Dawoud and jabar Jasim, Najaf, Press of Arts, 1973, page 165.

(41) Al-Mazrabani, Abu Abdullah Muhammad Bin Umran (384 H) Mujam Al-Sharaa, examined by Abid Alsataar Ahmed Faraaj, Cairo, Maktabat Eissa AlHalabi, 1960, page 202.

(42) Abi Sulma, Zuhair: Sharah Diwan Zuhair Bin Abi Sulma by Abu Alabas Thaalab, Beirut, House of Arab Books, 2004, page 54.

(43) The Tongue of Arabs, page 70.

(44) Altabriizi, Sharah Al-Qasaaiyed AlAshar, examined by Muhammad Abed Al-Hameed, Cairo, Muhamad Ali and His Sons Bookshop and Press.

(45) Gumaiyeh: Diwan Umru Bin Qumaiyeh examined by Hassan Al-Sairafi, Cairo, Institute of Arab Manuscripts, 1965, page 93.

(46) The Tongue of Arabs, page 405.

\section{REFERENCES}

[1] Al-Anbari, A. B. A. (1965). (NI) Explication of the Seven Long Poems in the Pre-Islamic Era, T: Abdul Salam Haroun, Cairo: Dar Al-Maaref.

[2] Al-Asha, M.B. (1992). Al-Diwan, explicated by Youssef Shukri, Beirut: Dar Al-Jeel.

[3] Albaglani, A. B. M.T. (2008). The Miracles of the Koran, Beirut: Scientific Books Publishing House.

[4] Al-Bakri, A. A. A. (1983). Dictionary of Foreignisms, examined by Mustafa Al-Saqa, Beirut: World of Books Publishing House.

[5] Al-Jader, M. A. (2002). Contemporary Reading in texts of poetic heritage, Baghdad: House of General Cultural Affairs

[6] Al-Jundi, Ai. (1977). Tarfa Ibn Al-Abed, Cairo: Dar al-Fikr Al-Arabi.

[7] Al-Jurjani, A. A. A. (1966). Mediation between Al-Mutanabi and his opponents, investigated by Mohammed Abu Fadl Ibrahim and Ali Bejaoui, Issa al-Babi and Halabi Cairo: Printing Press.

[8] Al-Kindi. (2008). Diwan Amru Al-Qais, examined by Abdul Rahman Al-Mastlawi, Beirut: Dar Al-Marefa.

[9] Al-Masri, I. A. A. (1995). Tahreer Al-Tahbeer, examined by Hefny Mohamed Sharaf, Committee for the Revival of Islamic Heritage, Cairo.

[10] Asfour, J. (1992). The Artistic Image in the Critical and Rhetorical Heritage of the Arabs, Beirut: Cultural Center.

[11] Bou Hassoun. H. (2002). 'Stylistics and Literary Text', Al-Mawkaf Al-Adabi Magazine, No. 378.

[12] Hamwi, Y. (1979). Dictionary of countries, the revival of the Arab heritage, Arab History Foundation, Beirut.

[13] Hassan, T. (1995). Arabic Language: Meaning and Construction, Maktabat Al-Thagafah, Casablanca.

[14] Ibn Jani, A. A. (1952). Al-Khaaays, examined by Mohammed Ali Najjar, Dar al-Kitab al-Arabi, Beirut (illustrated edition of Dar al-Kutub).

[15] Ibn Mandhour. (2000). A.I. M.: Lissan Al-Arab. Beirut: Dar Saadir.

[16] Ismail, E. (1981). Contemporary Arab Poetry and its Issues and Artistic and Moral Phenomena, Dar Al-Awda and Dar AlThaqafa, Beirut.

[17] Jandal, S. J. (1987). Al-Diwan, Sanaat Mohammed bin Hassan Ahwal, examined by Fakhr Al-Din Qubawa, 2nd edition, Beirut: House of Scientific Books.

[18] Junaidel, S.A. (1990). Dictionary of the places in the Ten Poetry Masterpieces in the Pre-Islamic Era, Idarat Al-Nashar Wathagafah Al-Jamiyeh.

[19] Marzabani, A. A. M.O. (1960). Glossary of poets, the achievement of Abdul Sattar Ahmed Farraj, Issa Al-Halabi Publishing House.

[20] Tabrizi, A. Z. Y.A. (1965). Explication of the Ten Poems, investigated by Mohammed Mohiuddin Abdul Hamid, Cairo: Mohammed Ali Sobh \& Sons Printing Press, 2nd floor, Al-Azhar Square

[21] Thaalab A. Th. (2004). Explication of Diwan Zuhair bin Abi Salma, Beirut: the Arab Book Publishing House. 
Ahmed Al-Harahshah, Professor of Ancient Literature at Al-Bayt University, Jordan, graduated from Al-Mustansiriya University with a doctorate degree in ancient literature, worked in Malaysia and the Islamic Uni versity in Al-Medina Al-Munawarah. He now works at Al-Bayt University in Jordan. He published several articles in international peer-reviewed journals. Recently, he has published a book entitled 'Explication of Al-Harhashi: Arab Commentaries in Light of the Reasonable Interpretive Approach' in 2019 and has many participations in scientific conferences in Jordan and outside Jordan.

Khaled Al-Badayneh is Associate Professor of Abbasside Literature/Poetry, Tafila Technical University Arabic Department. He graduated from Mutah University with a doctorate degree in ancient literature. He worked in Al-Medina Al-Munawarah Islamic University and he has published a number of articles in international peer-reviewed journals. In addition, he has participated in several scientific journals domestically and internationally. 